\title{
Ecology of Mosquitoes (Diptera: Culicidae) in Areas of Serra do Mar State Park, State of São Paulo, Brazil. II - Habitat Distribution
}

\author{
Anthony Érico Guimarães ${ }^{+}$, Carla Gentile, Catarina Macedo Lopes, \\ Rubens Pinto de Mello
}

\author{
Laboratório de Diptera, Departamento de Entomologia, Instituto Oswaldo Cruz, Av. Brasil 4365, 21045-900 \\ Rio de Janeiro, RJ, Brasil
}

The mosquito (Diptera: Culicidae) ecology was studied in areas of Serra do Mar State Park, State of São Paulo, Brazil. Systematized biweekly human bait collections were made three times a day, for periods of 2 or 3 heach, in sylvatic and rural areas for 24 consecutive months (January 1991 to December 1992). A total of 24,943 adult mosquitoes belonging to 57 species were collected during 622 collective periods.

Aedes scapularis, Coquillettidia chrysonotum, Cq. venezuelensis, Wyeomyia dyari, Wy. longirostris, Wy. theobaldi and Wy. palmata were more frequently collected at swampy and at flooded areas. Anopheles mediopunctatus, Culex nigripalpus, Ae. serratus, Ae. fulvus, Psorophora ferox, Ps. albipes and the Sabethini in general, were captured almost exclusively in forested areas. An. cruzii, An. oswaldoi and An. fluminensis were captured more frequently in a residence area. However, Cx. quinquefasciatus was the only one truly eusynanthropic.

An. cruzii and Ae. scapularis were captured feeding on blood inside and around the residence, indicating that both species, malaria and arbovirus vectors respectively, may be involved in the transmission of these such diseases in rural areas.

Key words: mosquitoes - ecology - vectors - Serra do Mar - Brazil

The ecology of mosquitoes that are potential vectors of human and/or animal pathogens in areas of the Serra do Mar State Park - PESM, Picinguaba Nucleus, City of Ubatuba, State of São Paulo, is poorly understood (Figs 1a, 2a). The seasonal distribution of mosquitoes is described in the prior work. This study describes seasonal abundance related to four types of habitat associated with the park.

\section{MATERIALS AND METHODS}

Four collections sites were selected (A/B/C/D) in sylvatic and rural environments in PESM. Samples were taken biweekly in human bait during different periods of the day, for 24 consecutive months (January 1991 to December 1992). Descriptions of collection sites are as follows:

This work is part of the main author's PhD thesis and was accomplished with the help of CNPq, process no. 41.1613/88.

${ }^{+}$Corresponding author. Fax: +55-21-290.9339. E-mail: anthony@fiocruz.br

Received 17 December 1998

Accepted 4 November 1999
Site A: located along the margins of the Fazenda River in the swampy area of the sandy lands through along the 3,500 m of Fazenda Beach, which is the only sea level point of the park. Aquatic vegetation partially covers the swamp and so influence the local mosquito fauna (Fig. 1b).

Site $B$ : outside the beach zone, approximately $1,500 \mathrm{~m}$ from the sea. It typically consists of shrub vegetation cover and is frequently subjected to floods during the rainy season, creating small swampy habitats. The soil is sandy with leaf material in edaphication process (Fig. 1c).

Site $C$ : this is the most representative of the region's primitive forest, not only because of taller vegetation with orchids and bromeliads, but also for its humidity and temperature levels (Fig. 2b).

Site $D$ : this site, a clearing in a forested area, was chosen as a representative site of existing human activity in the interior of the park. One of the residences was selected to evaluate Culicidae cohabitation (Fig. 2c).

Biweekly collections in sites A, B and C were conducted in three periods each day: daylight (10:00-12:00 $\mathrm{h}$ and 14:00-16:00 $\mathrm{h}$ ) and nocturnal (18:00-21:00 h). In each sampling period two team members collected mosquitoes by mouth aspirators using themselves as attractant. 
Human-bait collection was also conducted in site D biweekly and simultaneously in three different situations: inside the house, catching not only specimens attracted by man but also those resting on the internal walls; outside the house, catching mosquitoes attracted by human-bait and also those resting on the external walls of the house; and around the house, collecting specimens attracted by human-bait at the margins of the forest that surrounds the house, in distances never more than 50 $\mathrm{m}$. However, collections were only conducted from 18:00-21:00 h.

Collected mosquitoes were killed by chloroform and arranged in labeled small boxes. Mosquitoes were returned to the laboratory where they were identified according to classic literature and systematic proposals of Harbach and Kitching (1998) and Judd (1996, 1998) for the Sabethini tribe. Specimens were incorporated in the Entomological Collection, Entomology Department, Instituto Oswaldo Cruz, under the title of "Atlantic Forest Collection".

Mosquito species site preferences were determined by using Williams averages $\left(\mathrm{X}_{\mathrm{w}}\right)$ according to the definitions of Haddow $(1954,1960)$ and Forattini et al. (1981).

Statistical analysis and graphical representation were not made for all species. To evaluate the preference of the species for a certain type of habitat, there were considered only the species collected with a total number of individuals greater than $1 \%$ of its subfamily or tribe total number of collected specimens in at least one of the exclusively sylvatic environment, sites $A, B$ and $C$. To evaluate the species behavior toward the rural residence (site D), were selected for the analysis only the species with a total number of collected individuals greater than $1 \%$ of the total collected specimens in site D.

\section{RESULTS}

Preferences for sampling sites - Two aspects were especially evident: the great diversity of Culicidae species present and the clear preference of some of them for certain habitats. This distribution was directly associated to the characteristics of the 47.000 ha of Picinguaba Nucleus of PESM. Four different biotopes were characterized in the previously described collection sites (Figs 1b, c, 2b, c).

This habitat association is clearly seen in the swampy areas of site A and in the flooded areas of site B, where Coquillettidia chrysonotum predominates. In sites B and C, both in typical Atlantic Forest areas, the greatest species diversity was observed, with Sabethini tribe members occurring primarily in these areas (Table I).

Site D was located in one of the residences inside PESM, and was characterized by the inclu- sion of synanthropic species. Among them, Culex quinquefasciatus stands out, as it was found exclusively at that site (Fig. 3). Species such as Anopheles cruzii, Aedes scapularis, Cq. chrysonotum and $C q$. venezuelensis were also present in these samplings.

In the Anophelinae species studied $A n$. fluminensis preferred site $\mathrm{D}$ the most, followed by An. cruzii and An. oswaldoi. For the sylvatic environment, these three species preferred first site B, characterized by shrub-like vegetation, then site $\mathrm{C}$, with taller vegetation, and then site $\mathrm{A}$, the swampy area nearby the beach. An. mediopunctatus preferred the low scrub with temporary forest pools of site B.

Cx. quinquefasciatus was present exclusively in site D. Cx. nigripalpus was captured in forested environments: sites B and C (Table I, Fig. 3).

The Coquillettidia affinity with site A is associated with the offer of specific breeding sites to support the development of immature forms. This is evident with Williams' mean analyses for the two species found at PESM. For both $C q$. chrysonotum and $C q$. venezuelensis we verified the greatest preference for site $\mathrm{A}$, followed by site $\mathrm{D}$, $\mathrm{B}$ and $\mathrm{C}$, in this order (Table I, Fig. 3).

Psorophora ferox and Ps. albipes were rarely observed in site D and concentrated their greatest incidences was concentrated in the denser forest site samplings (Table I, Fig. 3).

Members of Sabethini tribe, generally considered sylvatic mosquitoes, were rarely present in the site D collections (Fig. 3). Among Sabethini species at this site, Runchomyia reversa was the one that occurred most frequently. Ru. frontosa was captured exclusively in the sylvatic environments of sites C, B and A, respectively (Table I, Fig. 3).

The two species of Trichoprosopon captured, $T r$. digitatum and Tr. pallidiventer, clearly preferred site C. Tr. digitatum presented few specimens in site $\mathrm{D}$ and $\mathrm{B}, \mathrm{X}_{\mathrm{w}}=0.1$ and $\mathrm{X}_{\mathrm{w}}=0.5$, against $\mathrm{X}_{\mathrm{w}}=$ 4.2 in site C. Tr. pallidiventer occurred only in site $\mathrm{B}$ and in site $\mathrm{C}$, preferring this last one (Table I, Fig. 3).

The Wyeomyia occurred exclusively in the sylvatic environment, except for rare specimens of Wy. mystes and Wy. dyari collected at the forest domicile in site D. Although they both occurred at the residence, these two species presented different preferences for sylvatic environments. Wy. dyari was the only species in the genus to show a significant tendency for site $\mathrm{A}$, with $\mathrm{X}_{\mathrm{W}}=12.4$ verses $X_{w}=9.6$ in site $B, X_{w}=7.2$ in site $C$ and $X_{w}=0.2$ in site $\mathrm{D}$. Wy. mystes first preferred site $\mathrm{B}$, with $\mathrm{X}_{\mathrm{w}}$ $=18.8$, than $\mathrm{X}_{\mathrm{w}}=13.9$ for site $\mathrm{C}, \mathrm{X}_{\mathrm{w}}=1.0$ for site $A$ and $X_{w}=0.1$ for site D. Of other three studied species, Wy. confusa, Wy. aporonoma and specially 


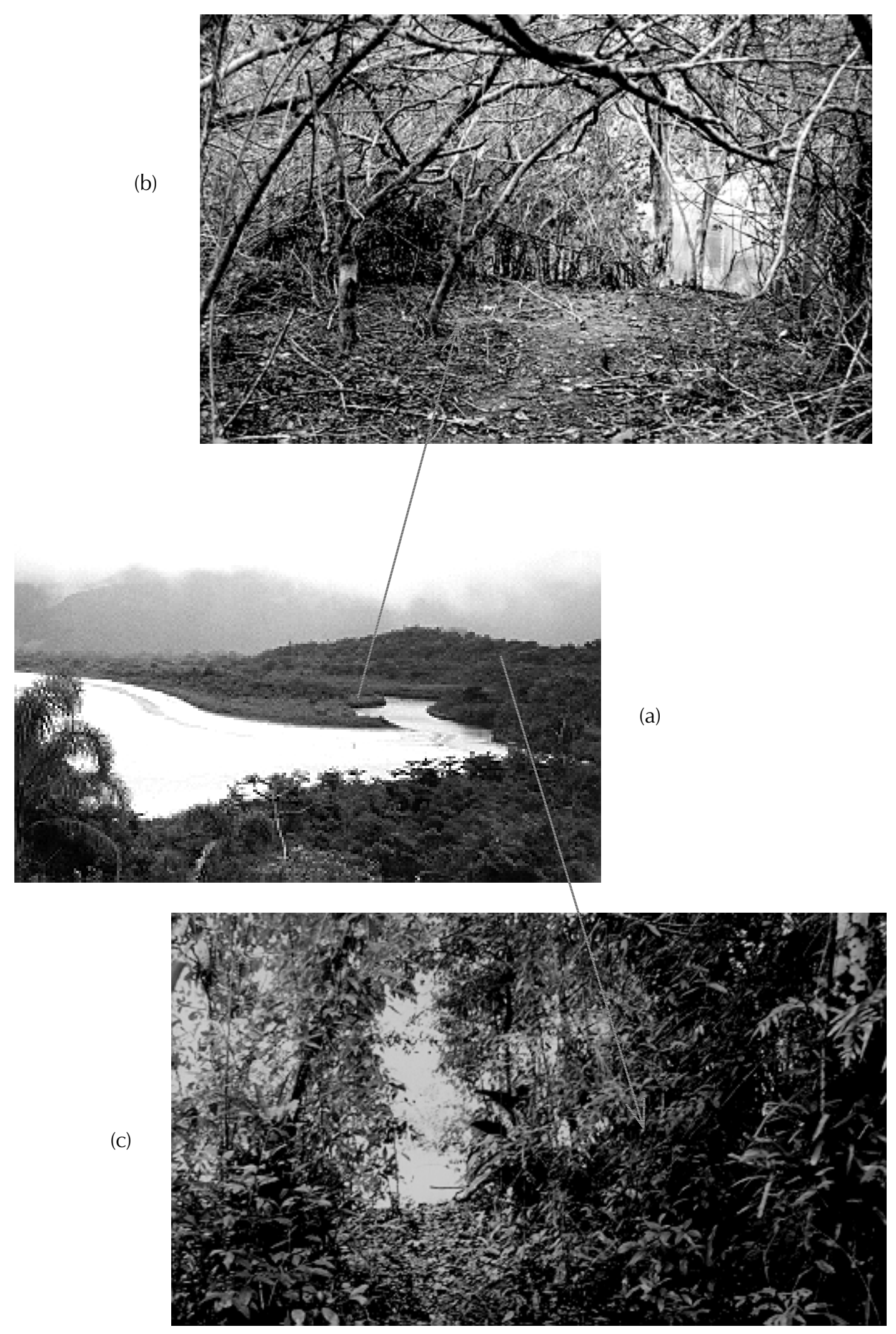

Fig. 1 - a: general view of the Picinguaba Nucleus of Serra do Mar State Park, State of São Paulo; b: highlighting Site A; c: Site B. 
TABLE I

Number $(\mathrm{N})$ and Willians averages $\left(\mathrm{X}_{\mathrm{w}}\right)$ of Culicidae captured by sampling site, Picinguaba Nucleus of Serra do Mar State Park, State of São Paulo, January 1991 to December 1992

\begin{tabular}{|c|c|c|c|c|c|c|c|c|c|}
\hline \multirow[t]{2}{*}{ Species } & \multicolumn{2}{|c|}{ Site A } & \multicolumn{2}{|c|}{ Site B } & \multicolumn{2}{|c|}{ Site C } & \multicolumn{2}{|c|}{ Site D } & \multirow{2}{*}{$\begin{array}{r}\text { Total } \\
\mathrm{N} \\
\end{array}$} \\
\hline & $\mathrm{N}$ & $\mathrm{X}_{\mathrm{W}}$ & $\mathrm{N}$ & $\mathrm{X}_{\mathrm{W}}$ & $\mathrm{N}$ & $\mathrm{X}_{\mathrm{W}}$ & $\mathrm{N}$ & $\mathrm{X}_{\mathrm{W}}$ & \\
\hline \multicolumn{10}{|l|}{ A N OP HEL I N A E } \\
\hline Anopheles cruzii & 14 & 0.8 & 207 & 8.7 & 60 & 3.4 & 298 & 15.0 & 579 \\
\hline An. albitarsis s. $l$. & 0 & 0.0 & 0 & 0.0 & 0 & 0.0 & 3 & 0.2 & 3 \\
\hline An. argyritarsis & 2 & 0.1 & 0 & 0.0 & 0 & 0.0 & 4 & 0.2 & 6 \\
\hline An. oswaldoi & 21 & 0.9 & 18 & 1.1 & 18 & 0.7 & 34 & 1.9 & 91 \\
\hline An. strodei & 1 & 0.1 & 0 & 0.0 & 0 & 0.0 & 0 & 0.0 & 1 \\
\hline An. intermedius & 3 & 0.1 & 1 & 0.1 & 2 & 0.1 & 8 & 0.4 & 14 \\
\hline An. fluminensis & 6 & 0.2 & 108 & 3.1 & 36 & 1.1 & 215 & 11.8 & 365 \\
\hline An. mediopunctatus & 27 & 1.5 & 216 & 8.2 & 116 & 5.9 & 0 & 0.0 & 359 \\
\hline Sub-total & 74 & 4.5 & 550 & 31.1 & 232 & 14.0 & 562 & 33.2 & 1,418 \\
\hline \multicolumn{10}{|c|}{ C U L I C I N A E (excluding Sabethini) } \\
\hline Culex nigripalpus & 0 & 0.0 & 183 & 7.2 & 103 & 5.2 & 0 & 0.0 & 286 \\
\hline Cx. quinquefasciatus & 0 & 0.0 & 0 & 0.0 & 0 & 0.0 & 207 & 9.3 & 207 \\
\hline Orthopodomyia albicosta & 0 & 0.0 & 1 & 0.1 & 0 & 0.0 & 0 & 0.0 & 1 \\
\hline Aedes serratus & 147 & 10.1 & 561 & 42.1 & 890 & 65.9 & 105 & 5.9 & 1,703 \\
\hline Ae. scapularis & 222 & 15.5 & 106 & 7.5 & 90 & 5.2 & 70 & 4.3 & 488 \\
\hline Ae. fluviatilis & 0 & 0.0 & 0 & 0.0 & 15 & 0.3 & 1 & 0.1 & 16 \\
\hline Ae. fulvus & 16 & 0.5 & 5 & 0.3 & 233 & 9.6 & 0 & 0.0 & 254 \\
\hline Ae. terrens & 1 & 0.1 & 1 & 0.1 & 9 & 0.4 & 1 & 0.1 & 12 \\
\hline Coquillettidia chrysonotum & 3,682 & 125.6 & 3,848 & 58.1 & 1,012 & 39.1 & 2,872 & 71.7 & 11,414 \\
\hline Cq. venezuelensis & 502 & 24.7 & 379 & 13.0 & 230 & 10.3 & 501 & 22.0 & 1,612 \\
\hline Psorophora ferox & 138 & 6.1 & 254 & 13.6 & 894 & 52.3 & 14 & 0.5 & 1,300 \\
\hline Ps. albipes & 47 & 2.1 & 159 & 8.6 & 553 & 31.3 & 18 & 0.9 & 777 \\
\hline Haemagogus leucocelaenus & 0 & 0.0 & 4 & 0.2 & 12 & 0.8 & 0 & 0.0 & 16 \\
\hline Ha. capricornii & 0 & 0.0 & 3 & 0.2 & 0 & 0.0 & 0 & 0.0 & 3 \\
\hline Uranotaenia geometrica & 0 & 0.0 & 0 & 0.0 & 2 & 0.1 & 1 & 0.1 & 3 \\
\hline Sub-total & 4,755 & 215.2 & 5,504 & 257.5 & 4,043 & 294.9 & 3,790 & 145.8 & 18,092 \\
\hline \multicolumn{10}{|l|}{ SABETHINI } \\
\hline Shannoniana fluviatilis & 0 & 0.0 & 0 & 0.0 & 1 & 0.1 & 0 & 0.0 & 1 \\
\hline Trichoprosopon digitatum & 0 & 0.0 & 11 & 0.5 & 64 & 4.2 & 1 & 0.1 & 76 \\
\hline Tr. pallidiventer & 0 & 0.0 & 9 & 0.5 & 142 & 3.2 & 0 & 0.0 & 151 \\
\hline Tr. simile & 0 & 0.0 & 1 & 0.1 & 5 & 0.3 & 0 & 0.0 & 6 \\
\hline Runchomyia lunata & 0 & 0.0 & 6 & 0.3 & 1 & 0.1 & 0 & 0.0 & 7 \\
\hline$R u$. reversa & 14 & 0.8 & 26 & 1.4 & 45 & 2.3 & 6 & 0.4 & 91 \\
\hline Ru. theobaldi & 26 & 0.3 & 7 & 0.4 & 5 & 0.2 & 0 & 0.0 & 38 \\
\hline$R u$. frontosa & 23 & 1.1 & 60 & 3.6 & 96 & 6.3 & 0 & 0.0 & 179 \\
\hline Ru. humboldti & 1 & 0.1 & 1 & 0.1 & 4 & 0.1 & 0 & 0.0 & 6 \\
\hline Wyeomyia. dyari & 259 & 12.4 & 172 & 9.6 & 119 & 7.2 & 3 & 0.2 & 553 \\
\hline Wy. confusa & 9 & 0.5 & 63 & 2.1 & 62 & 3.5 & 0 & 0.0 & 134 \\
\hline Wy. mystes & 18 & 1.0 & 268 & 18.8 & 246 & 13.9 & 2 & 0.1 & 534 \\
\hline Wy. aporonoma & 20 & 1.1 & 107 & 7.5 & 431 & 27.3 & 0 & 0.0 & 558 \\
\hline Wy. personata & 0 & 0.0 & 3 & 0.2 & 9 & 0.3 & 0 & 0.0 & 12 \\
\hline Wy. shannoni & 4 & 0.1 & 3 & 0.2 & 102 & 5.4 & 0 & 0.0 & 109 \\
\hline Wy. oblita & 0 & 0.0 & 1 & 0.1 & 0 & 0.0 & 0 & 0.0 & 1 \\
\hline Wy. theobaldi & 190 & 5.7 & 16 & 0.8 & 40 & 1.2 & 0 & 0.0 & 246 \\
\hline Wy. flabelata & 25 & 1.5 & 142 & 9.2 & 227 & 14.7 & 0 & 0.0 & 394 \\
\hline Wy. pilicauda & 3 & 0.2 & 2 & 0.1 & 6 & 0.3 & 0 & 0.0 & 11 \\
\hline Wy. splendida & 28 & 1.6 & 73 & 4.5 & 246 & 13.2 & 3 & 0.2 & 350 \\
\hline Wy. palmata & 39 & 1.3 & 11 & 0.6 & 13 & 0.7 & 0 & 0.0 & 63 \\
\hline Wy. longirostris & 160 & 8.5 & 71 & 4.9 & 94 & 4.3 & 0 & 0.0 & 325 \\
\hline Wy. quasilongirostris & 18 & 0.9 & 95 & 4.8 & 60 & 3.6 & 5 & 0.2 & 178 \\
\hline
\end{tabular}




\begin{tabular}{lrrrrrrrrr} 
Wy. davisi & 18 & 1.0 & 31 & 1.5 & 22 & 1.2 & 0 & 0.0 & 71 \\
Wy. bonnei & 33 & 2.1 & 97 & 4.7 & 205 & 10.8 & 0 & 0.0 & 335 \\
Wy. lassalli & 0 & 0.0 & 0 & 0.0 & 56 & 0.6 & 0 & 0.0 & 56 \\
Limatus flavisetosus & 25 & 1.4 & 111 & 5.8 & 363 & 21.2 & 0 & 0.0 & 499 \\
Li. durhami & 40 & 2.5 & 26 & 1.4 & 64 & 3.0 & 0 & 0.0 & 130 \\
Li. pseudomethisticus & 17 & 1.0 & 55 & 3.0 & 218 & 13.9 & 0 & 0.0 & 290 \\
Sabethes quasicyaneus & 2 & 0.1 & 1 & 0.1 & 0 & 0.0 & 0 & 0.0 & 3 \\
Sa. intermedius & 0 & 0.0 & 1 & 0.1 & 0 & 0.0 & 0 & 0.0 & 1 \\
Sa. identicus & 0 & 0.0 & 3 & 0.2 & 16 & 0.4 & 0 & 0.0 & 19 \\
Sa. fabricii & 0 & 0.0 & 2 & 0.1 & 1 & 0.1 & 0 & 0.0 & 3 \\
Sa. soperi & 0 & 0.0 & 2 & 0.1 & 1 & 0.1 & 0 & 0.0 & 3 \\
\hline Sub-total & 972 & 54.7 & 1,477 & 97.6 & 2,964 & 198.7 & 20 & 0.9 & 5,433 \\
\hline Total & 5,801 & 310.8 & 7,531 & 422.5 & 7,239 & 581.6 & 4,372 & 192.8 & 24,943 \\
\hline
\end{tabular}

Wy. shannoni all demonstrated a preference for site C (Fig. 3). Among the eight Wy. (Phoniomyia) species analyzed, three were predominately captured in site A: Wy. theobaldi, Wy. palmata and Wy. longirostris. Another three were captured principally in site C: Wy. flabelata, Wy. splendida and Wy. bonnei. The other two, Wy. quasilongirostris and Wy. davisi, in site B. Of these, only Wy. splendida and Wy. quasilongirostris were captured at site D. Wy. theobaldi demonstrated a clear preference for site $A$ with $X_{w}=5.7$ against $X_{w}=1.2$ in site $\mathrm{C}$ and $\mathrm{X}_{\mathrm{w}}=0.8$ in site $\mathrm{D}$ (Table I, Fig. 3).

Limatus flavisetosus, Li. durhami and $\mathrm{Li}$. pseudomethisticus were captured exclusively in sylvatic habitats, most frequently at site $\mathrm{C}$ (Table I, Fig. 3).

Intra, peri and extradomicile frequency - According to Povolny (1971), the Culicidae found in site D may be classified by their synanthropic degree as: eusynanthropic, hemisynanthropic and asynanthropic.

The first group was represented exclusively by $C x$. quinquefasciatus, restricted to the captures in site D and totally absent from the sylvatic environments of sites A, B and C. The high degree of synanthropy of this Culicinae becomes evident by the results obtained in the three environments: $X_{w}$ $=5.2$ indoors, $X_{\mathrm{w}}=2.1$ outside the residence and $\mathrm{X}_{\mathrm{w}}=1.4$ around it, in the yard, closer to the forest (Fig. 4).

An. cruzii and An. fluminensis, were found invading the residence. For An. cruzii the definition as a hemisynanthropic species seems proper, although its greatest preference was arround the residence $\mathrm{X}_{\mathrm{w}}=8.2$, its presence outside and inside it was significant, respectively $X_{\mathrm{w}}=3.1$ and $\mathrm{X}_{\mathrm{w}}=$ 1.4. An. fluminensis behaved as asynanthropic, with $X_{\mathrm{w}}=9.9$ around the residence, $\mathrm{X}_{\mathrm{w}}=0.5$ outside and $\mathrm{X}_{\mathrm{w}}=0.1$ inside it (Fig. 4).

Ae. scapularis and Ae. serratus behaved at site $\mathrm{D}$ in similar ways, with a greater tendency to stay around the residence, other than outside it and or inside it (Fig. 4). Cq. chrysonotum and Cq. venezuelensis showed the same pattern as these Aedes, but with almost 20 times the number of specimens (Fig. 4).

\section{DISCUSSION}

Preferences for sampling sites - There are many reports on Culicidae incidence a in the Atlantic Forest areas of the Southeastern Region of Brazil. Forattini et al. (1968, 1978a,b, 1981, 1986a,b, 1987a,b, 1989, 1990, 1993a,b,c, 1995a,b), Guimarães et al. (1989, 1991, 1992), Lopes (1996) and Ferreira (1997) approached the presence of these mosquitoes comparatively in two or more capture sites in the same region. However, the majority of these authors refer to the possible domiciliation processes that the mosquito fauna goes through toward co-habitation with man. In the present study, we comparatively analyzed the presence of mosquitoes in three exclusively forested environment sites.

Comparing sylvatic captures with the captures in the residence, represented by site $\mathrm{D}$, in the Picinguaba Nucleus of PESM, only An. cruzii, An. oswaldoi, An. fluminensis and $C x$. quinquefasciatus were found preferably in this site. Ae. serratus, Ae. scapularis, Cq. chrysonotum, Cq. venezuelensis and $R u$. reversa presented the higher occurrences in sylvatic environment. Ps. albipes, Tr. digitatum, Wy. dyari, Wy. mystes, Wy. quasilongirostris and Wy. splendida were rarely found in site D.

Forattini et al. (1968) observed that the frequency of An. cruzii in residences might vary according to their proximity to the forest. An. cruzii has been demonstrates as the transmitter of malaria in Southeastern and Southern areas of Brazil and attacks man both around and inside houses (Deane et al. 1971, 1984, Azevedo 1997). In our samplings, although the greatest occurrence of $A n$. cruzii was observed in the residence, its presence 
(b)

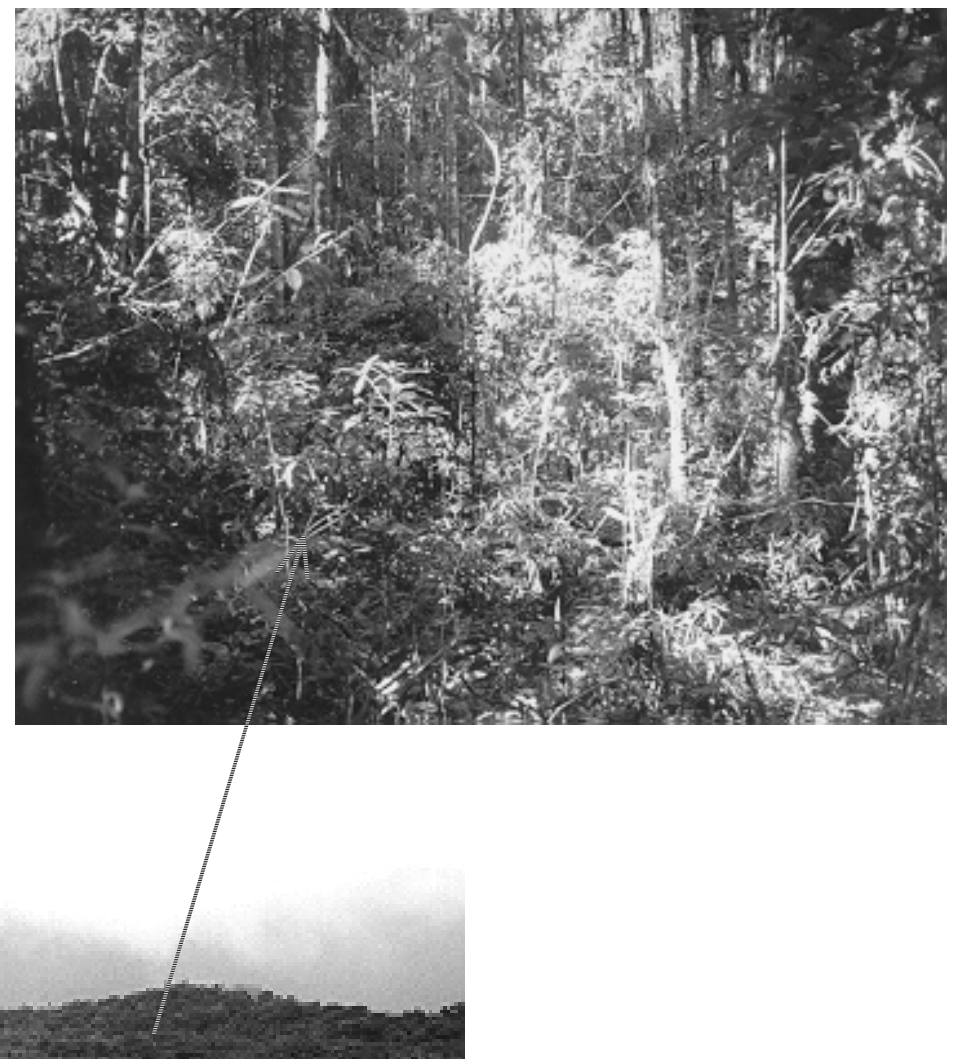

(a)

(c)

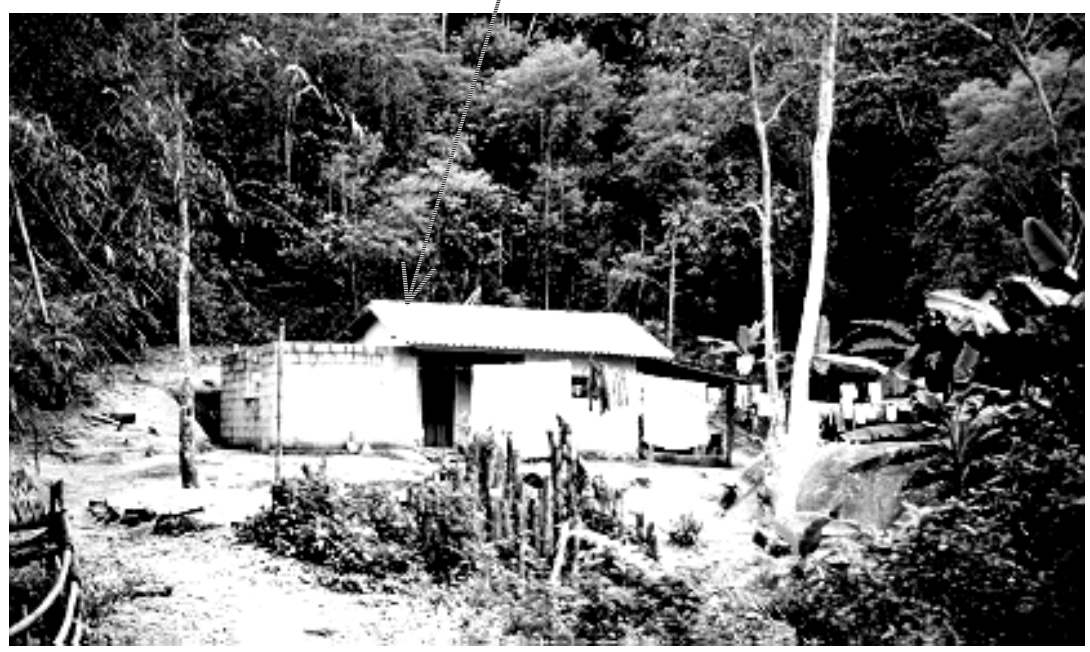

Fig. 2 - a: general view of the Picinguaba Nucleus of Serra do Mar State Park, State of São Paulo; b: highlighting Site C; c: Site D. 


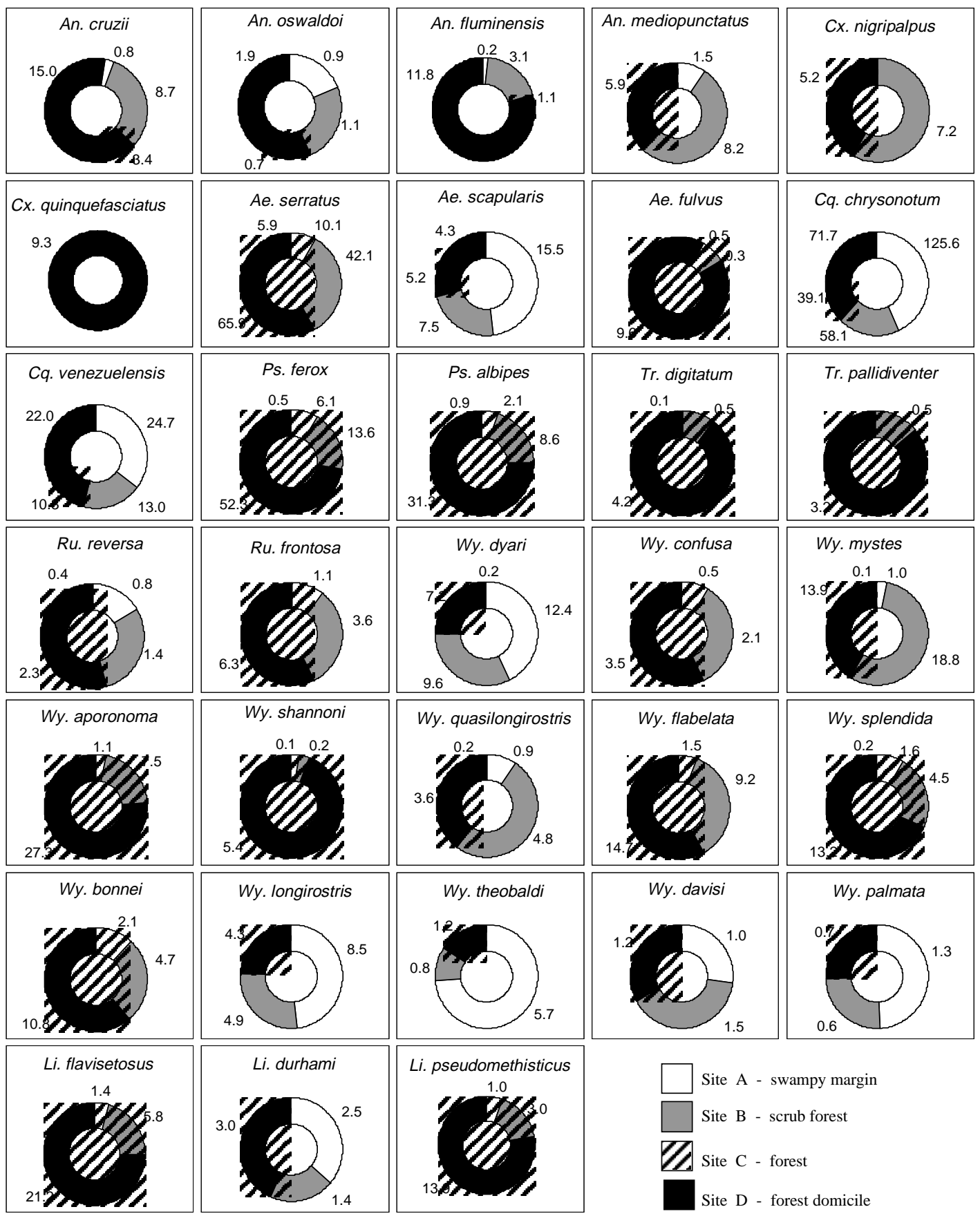

Fig. 3: habitat preferences of Culicidae species, according to calculation of Williams averages $\left(\mathrm{X}_{\mathrm{w}}\right)$, Picinguaba Nucleus of Serra do Mar State Park, State of São Paulo, January 1991 to December 1992. Site A = swampy margin; Site B = scrub forest; Site C = forest; Site $\mathrm{D}=$ forest domicile.

in sylvatic environments was common (Fig. 3). This distribution is in agreement with the observations of Forattini et al. (1990), that described the migratory capacity of this Anophelinae between the forest and residences for the purpose of hematophagic activity. In more recent studies,
Forattini et al. (1993a,c) considered An. cruzii as asynanthropic even after human occupation and subsequent environmental modification. Although able to invade the domicile for the hematophagic activity, this Anophelinae maintains the sylvatic environment as its natural habitat. 

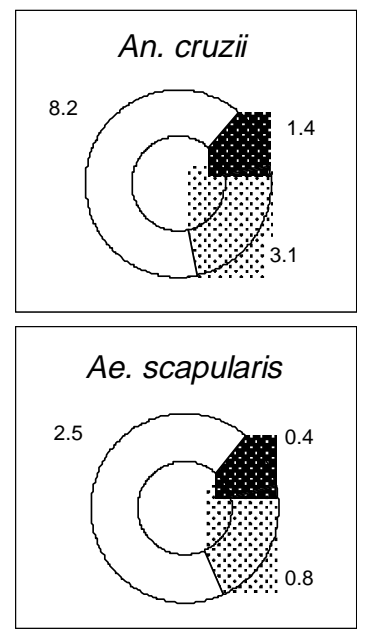

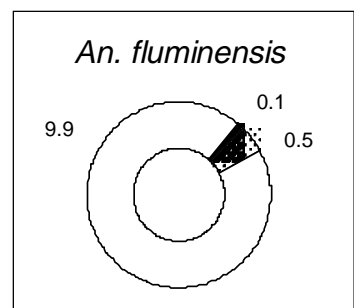

Cq. chrysonotum

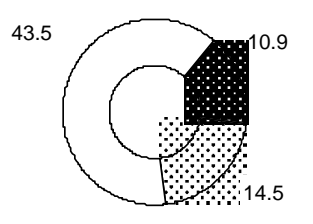

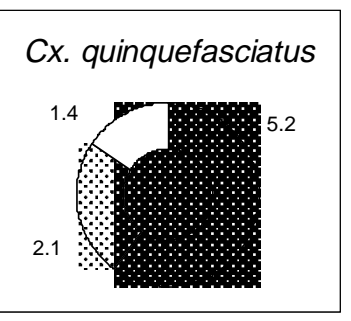

Cq. venezuelensis

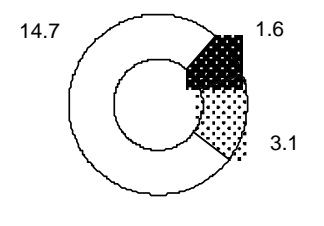

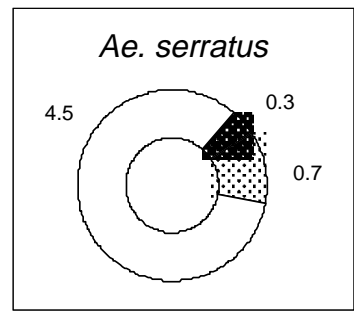

Intradomicile

Peridomicile

Extradomicile

Fig. 4: Culicidae species frequency inside (intradomicile), around (peridomicile) and outside (extradomicile) the residence at site $\mathrm{D}$, according to the calculation of Williams averages, during 18:00-21:00 hr period, Picinguaba Nucleus of Serra do Mar State Park, State of São Paulo, January 1991 to December 1992.

The distribution of An. oswaldoi and An. fluminensis was similar to An. cruzii, although this latter occurred with a lower number of specimens. Lourenço-de-Oliveira et al. (1989), studying Anophelinae in the State of Rondônia, and Ferreira (1997), in the Atlantic Forest of the State of Rio de Janeiro, captured An. oswaldoi in the residence surroundings as well as in forested environment. Guimarães et al. (1994) reported occurrences of An. fluminensis in forested environment as well as in collections inside residence; in our studies they were captured preferably in the latter (Fig. 3).

Cx. quinquefasciatus is historically considered as a typical urban mosquito (Causey et al. 1945, Deane 1951, 1954, Forattini et al. 1978b, 1993c and Guimarães et al. 1989). In the present study, this was the only truly eusynanthropic species found (Fig. 3). Roberts et al. (1981) and Lourençode-Oliveira and Heyden (1986), observed that in rural areas, where houses are distant from each other, $C x$. quinquefasciatus becomes scarce. However, by the present observations and by Guimarães et al. (1989), we believe that the hypothesis of Forattini et al. (1968) that this mosquito is still adapting itself to these areas should clearly characterize this mosquito behavior in that environment. It should also be considered that the area in which Lourenço-de-Oliveira and Heyden (1986) worked, was flooded and plenty of aquatic vegetation. This environment was highly favorable to the occurrence of other mosquito species in the residence, as for example Mansonia titillans, the most abundant species according to these authors.
Caught exclusively in sylvatic situations in our studies (Fig. 3), Cx. nigripalpus has demonstrated in other studies a more varied behavior. Lourençode-Oliveira (1984) collected this Culicinae in a deeply altered area in the State of Rio de Janeiro and Forattini et al. (1993c) reported its preference for anthropic modified environment. Forattini et al. (1995b) remarked that the behavior of $C x$. nigripalpus in getting close to residences increases its epidemiological importance, specially because this mosquito has been frequently incriminated as transmitter of the St. Louis encephalitis and was considered so in Vale da Ribeira region, in the State of São Paulo.

There are many reports of Ae. scapularis being captured in great number of specimens at sylvatic environment (Davis 1945, Causey \& Santos 1949, Rachou et al. 1955, Neves 1972, Guimarães \& Arlé 1984, Lourenço-de-Oliveira 1984, Forattini et al. 1986a,b). We also found the greater number of individuals in sylvatic sites. However, it was observed that a great part of this incidence was for site A that, although in sylvatic environment, is an open beach area, and close to locations where man frequents (Fig. 3). If we evaluate the occurrences in sites $\mathrm{A}$ and $\mathrm{D}$ together, we can better observe the potentiality of Ae. scapularis in the domiciliation process whenever man is introduced in sylvatic areas.

Forattini (1961), Forattini et al. (1978a,b, 1981, 1993c, 1995a) and Guimarães et al. $(1989,1994)$ referred to the significant domiciliation tendency of Ae. scapularis. In studies made at Vale da 
Ribeira, Forattini et al. (1978b) speculated that the epidemic of encephalitis occurred in that area may have been associated with the incidence of this Culicinae in the residential environment. Forattini et al. (1987b) examining blood found in engorged mosquitoes in this same region, observed that $80 \%$ of the Ae. scapularis specimens had fed on man.

This study demonstrated that Ae. serratus was preferentially captured is sylvatic environments. Previous studies in Brazil have found the same preference (Forattini et al. 1978a, 1981, 1986a,b, 1995a, Guimarães et al. 1992, 1994, Lopes 1996, Ferreira 1997). However, Forattini et al. (1993c) reported that Ae. serratus and also Ae. scapularis were captured in environments modified by man.

Reports on Ae. fulvus incidence referred to them being collected in forested areas where man's activity is not mentioned (Guimarães et al. 1994, Forattini et al. 1995b). Confirming this tendency, Ae. fulvus was only present in the captures taken in sylvatic environment, with clear preference for better preserved forest (Fig. 3).

Generally, Coquillettidia mosquitoes are considered aggressive, avid blood feeders of man and/ or other animals. Perhaps due to this behavior or to their attraction to artificial light, the two studied species, Cq. chrysonotum and Cq. venezuelensis, were collected in high incidence in the vicinities of the residence in site D (Fig. 3). Guimarães et al. (1989) reported the occurrence of these two species in the residence. Forattini et al. (1978b) reported similar distribution for Cq. chrysonotum in residential samplings as well as in the sylvatic ones. Forattini et al. (1978b, 1981, 1986b) and Lourençode-Oliveira (1984) captured Cq. venezuelensis more frequently in forested areas.

Ps. ferox and Ps. albipes maintained in our studies clear preference for the sylvatic environment as demonstrated by others (Forattini et al. 1981, 1986b, 1993c, Guimarães et al. 1989, 1994).

Most Sabethini species occurred preferably in samplings taken in sylvatic environment. The rare presences of some of these species in site $\mathrm{D}$ were by chance or due to the search for a blood meal. The willing of $R u$. reversa to invade site $\mathrm{D}$ was also seen by Forattini et al. (1968).

Forattini et al. (1978a), in Vale da Ribeira, also observed that the Sabethini are much more abundant in sylvatic areas. However, the same authors in the same period and location (Forattini et al. $1978 \mathrm{~b}$ ) found rare occurrences of some of them in areas very close to residences. These species were also captured in similar circumstances in the present study (Fig. 3).

We captured $T r$ digitatum only once at site D (Table I), and Tr. pallidiventer was exclusively captured in sylvatic areas. Both species preferred site
$\mathrm{C}$, where the forest was denser and more preserved (Fig. 3). Forattini et al. (1986a) found similar incidences for Tr. pallidiventer and Guimarães et al. (1994) for Tr. digitatum.

Among the Wyeomyia species studied, Wy. dyari prefered the swampy areas of site A. The occurrences of Wy. confusa, Wy. shannoni and Wy. aporonoma were greatest in denser forested areas (Fig. 3). This data is in accordance to Forattini et al. (1968, 1986a, 1993) and Guimarães et al. (1989) referred to sporadic occurrences of Wy. confusa in residences. Wy. mystes presented the greatest incidence at forested areas (Fig. 3), as observed by Guimarães et al. (1989).

The Wy. (Phoniomyia) species could be divided into groups related to the sampling sites. With significant incidences at sites B and C we found $W y$. quasilongirostris, Wy. flabelata, Wy. splendida and Wy. bonnei, and at site A, Wy. longirostris, Wy. theobaldi, Wy. davisi and Wy. palmata (Fig. 3). Wy. (Phoniomyia) lay their eggs almost exclusively in the central water filled cavity in bromeliads. Incidental to the objectives of the present study, we collected immature forms, especially of $W y$. (Phoniomyia) in site A, in the accumulated water between leaves of many plants. The choice for this alternative breeding site, very frequent in site A, may be related to the greatest incidence of these species.

Forattini et al. (1978a, 1986a, 1993c), Lourenço-de-Oliveira (1984), Guimarães et al. $(1989,1994)$ and Lopes (1996) reported the capture of these Wy. (Phoniomyia) species in sylvatic environment and with vegetation coverage similar to that of the present study. Forattini et al. (1968) referred to the occurrence of Wy. longirostris specimens in residences. Similar occurrence was observed for Wy. quasilongirostris (Fig. 3).

Guimarães and Arlé (1984) referred to $\mathrm{Li}$. durhami as a Sabethini close associated with man because its immature forms are frequently found in artificial breeding sites formed due to human activity as well as hematophagous habits. In our studies, the three Limatus species captured, $L i$. durhami, Li. flavisetosus and Li. pseudomethisticus, followed the observations of Forattini et al. (1978a, 1993c), Lourenço-de-Oliveira (1984), Guimarães et al. $(1989,1994)$ and Ferreira (1997), that reported them exclusively in sylvatic environment (Fig. 3).

Intra, peri and extradomicile frequency - The presence of man and the accessories indispensable to his survival turns the residence into a place with proper conditions for certain mosquito species. Shelter, guaranteed blood meal, more moderated and constant climatic conditions and, in some cases, the breeding sites, are some of these attractive factors. 
$C x$. quinquefasciatus, the only truly eusynanthropic species, had more intense presence inside and around the residence, with incidence outside it considered as occasional (Fig. 4). Causey et al. (1945), Deane $(1951,1954)$, Forattini et al. (1978b, 1987b), Gomes et al. (1987) and Guimarães et al. (1989), in different Brazilian regions, similarly observed the domestic incidence of this Culicinae.

The possible involvement of An. cruzii in the transmission of etiologic agents of human and simian malaria in the southeastern and south of Brazil has been reported through the years by many authors. However, with the exception of the observation of Forattini (1961) and Forattini et al. (1968), the majority of the studies did not report an important presence of An. cruzii inside the domicile. At most, as in our studies (Fig. 4), the incidences were restrict to the vicinities around the residence or to its interior solely for the purpose of a blood meal (Rachou 1946, Rachou et al. 1958, Deane et al. 1971, 1984, Forattini et al. 1978b, 1993a, Gomes et al. 1987, Azevedo 1997).

Guimarães et al. (1994) captured An. fluminensis in different sylvatic locations at PNI and referred to rare occurrences inside the residence. These data, also found in our studies (Fig. 4 ), and the exclusive preference for sylvatic environments reported by Lourenço-de-Oliveira et al. (1989) in the State of Rondônia, confirm that these rare occurrences inside and around the domicile were sporadic.

The epidemiologic importance of Ae. scapularis in the potential arbovirus transmission on the shores of State of São Paulo is supported in our studies by its presence inside and around the residence (Fig. 4). Forattini (1961), Forattini et al. (1978b, 1987b, 1995a) and Guimarães et al. (1989) reported remarkable incidences of Ae. scapularis inside the residence and considered it as endophilic. Forattini et al. (1987b, 1989, 1990) and Guimarães et al. (1987) demonstrated that this tendency to residence environment is also based in the great number of Ae. scapularis specimens captured feeding on blood of domestic animals and for its remaining around the residence after blood feeding.

Forattini et al. (1968) related significant Ae. serratus incidences inside the residence with annual cycles of different sizes. In our studies we verified the possibility of residence invasion (Fig. 4). However, it seems to follow the already observed tendency for living outside (Forattini et al. 1978a, 1981, 1986a,b, Guimarães et al. 1992, Lopes 1996, Ferreira 1997).

Cq. chrysonotum and Cq. venezuelensis, especially the first one, were captured indoors with significant incidences (Fig. 4). Guimarães et al.
(1989), studying different kinds of residence in the Atlantic forest areas in the State of Rio de Janeiro, referred to the constant occurrence of both species around and inside the residence. However, they remark that the greatest incidences were outside it. This is in agreement with our observations. Shannon (1931) and Giglioli (1948) considered that the presence of Coquillettidia species in the residence was conditioned to the proximity to the breeding sites. Yet, in PESM the studied residence was approximately $1,000 \mathrm{~m}$ from the breeding sites and so, the occurrences inside and around it demonstrate that, in addition to the strong attraction exerted by light, these mosquitoes are capable of crossing considerable distances in their search for a food source.

\section{REFERENCES}

Azevedo AL 1997. Aspectos da Epidemiologia da Malária e da Biologia de Anopheles (Kerteszia) cruzii Dyar \& Knab em Vales Montanhosos do Sistema de Mata Atlântica, MSc Thesis, Instituto Oswaldo Cruz, Rio de Janeiro, 94 pp.

Causey OR, Santos GV 1949. Diurnal mosquitoes in an area of small residual forests in Brazil. Ann Ent Soc Am 42: 471-482.

Causey OR, Deane MP, Costa O, Deane LM 1945. Studies on the incidence and transmission of filaria, Wuchereria bancrofit, in Belém, Brazil. Am J Hyg 41: 143-149.

Davis DE 1945. The annual cycle of plants, mosquitoes birds and mammals in two Brazilian forests. Ecological Monographs 15: 243-295.

Deane LM 1951. Observações sobre alguns hábitos dos adultos de Culex fatigans, o principal transmissor de filariose bancroftiana em Belém, Pará. Rev Ser Esp Saúde Públ 4: 423-464.

Deane LM 1954. Dedetização domiciliária e transmissão da filariose bancroftiana em Belém, Pará. O Hospital 45: 187-206.

Deane LM, Deane MP, Ferreira-Neto JÁ, Almeida FB 1971. On the transmission of simian malaria in Brazil. Rev Inst Med Trop São Paulo 13: 311-319.

Deane LM, Ferreira-Neto JÁ, Lima MM 1984. Vertical dispersion of Anopheles (Kerteszia) cruzii in a forest in southern Brazil suggests that humam cases of simian origin be expected. Mem Inst Oswaldo Cruz. 79: 461-463.

Ferreira ZM 1997. Preferência Horária para a Hematofagia de Mosquitos (Diptera-Culicidae) em Áreas da Reserva Biológica do Tinguá, Estado do Rio de Janeiro, Brasil, Monography, Instituto Oswaldo Cruz, Fiocruz, Rio de Janeiro, 38 pp.

Forattini OP 1961. Some data on the domesticity of Aedes scapularis (Rondani) in São Paulo, Brazil. Mosquito News 21: 295-296.

Forattini OP, Gomes AC, Galati EAB, Rabelo EX, Iversson LB 1978a. Estudos ecológicos sobre mosquitos Culicidae no Sistema Serra do Mar, Brasil. 1 - Observações no ambiente extradomiciliar. Rev Saúde Pública 12: 297-325. 
Forattini OP, Gomes AC, Galati EAB, Rabelo EX, Iversson LB 1978b. Estudos ecológicos sobre mosquitos Culicidae no Sistema Serra do Mar, Brasil. 2 - Observações no ambiente domiciliar. Rev Saúde Pública 12: 476-496.

Forattini OP, Gomes AC, Natal D, Santos JLF 1986a. Observações sobre atividade de mosquitos Culicidae em mata primitiva da encosta no Vale da Ribeira, São Paulo, Brasil. Rev Saúde Pública 20: 1-20.

Forattini OP, Gomes AC, Natal D, Santos JLF 1986b. Observações sobre atividade de mosquitos Culicidae em mata primitiva da planície e perfis epidemiológicos de vários ambientes no Vale da Ribeira, São Paulo, Brasil. Rev Saúde Pública 20: 178-203.

Forattini OP, Gomes AC, Natal D, Kakitani I, Marucci D 1987a. Preferências alimentares de mosquitos Culicidae no Vale da Ribeira, São Paulo, Brasil. Rev Saúde Pública 21: 171-187.

Forattini OP, Gomes AC, Natal D, Kakitani I, Marucci D 1987b. Freqüência domiciliar e endofilia de mosquitos Culicidae no Vale da Ribeira, São Paulo, Brasil. Rev Saúde Pública 21: 188-192.

Forattini OP, Gomes AC, Natal D, Kakitani I, Marucci D 1989. Preferências alimentares e domiciliação de mosquitos Culicidae no Vale da Ribeira, São Paulo, Brasil, com especial referência a Aedes scapularis e a Culex (Melanoconion). Rev Saúde Pública 23: 919.

Forattini OP, Gomes AC, Santos JLF, Kakitani I, Marucci D 1990. Freqüência ao ambiente humano e dispersão de mosquitos Culicidae em área adjacente à Mata Atlântica primitiva da planície. Rev Saúde Pública 24: 101-107.

Forattini OP, Gomes AC, Santos JLF, Galati EAB, Rabelo EX, Natal D 1981. Observações sobre a atividade de mosquitos Culicidae, em mata residual do Vale da Ribeira, São Paulo, Brasil. Rev Saúde Pública 15: 557-586.

Forattini OP, Kakitani I, Massad E, Gomes AC 1993a. Studies on mosquitos (Diptera: Culicidae) and anthropic and environment. 1- Parity of blood seeking Anopheles (Kerteeszia) in SouthEastern, Brazil. Rev Saúde Pública 27: 1-8.

Forattini OP, Kakitani I, Massad E, Marucci D 1993b. Studies on mosquitos (Diptera: Culicidae) and anthropic and environment. 3 - Survey of adult stages at the rice irrigation system and the emergence of Anopheles albitarsis in SouthEastern, Brazil. Rev Saúde Pública 27: 313-325.

Forattini OP, Kakitani I, Massad E, Marucci D 1993c. Studies on mosquitos (Diptera: Culicidae) and anthropic and environment. 4 - Survey of resting adult and synanthropic behaviour in SouthEastern, Brazil. Rev Saúde Pública 27: 398-411.

Forattini OP, Kakitani I, Massad E, Marucci D 1995a. Studies on mosquitoes (Diptera: Culicidae) and anthropic environment. 9 - Synanthropy and epidemiological vector role of Aedes scapularis in SouthEastern Brazil. Rev Saúde Pública 29: 199207.

Forattini OP, Kakitani I, Massad E, Marucci D 1995b.
Studies on mosquitoes (Diptera: Culicidae) and anthropic environment. 10 - Survey of adult behaviour of Culex nigripalpus and other species of Culex (Culex) in SouthEastern Brazil. Rev Saúde Pública 29: 271-278.

Forattini OP, Lopes OS, Rabelo EX 1968. Investigações sobre o comportamento de formas adultas de mosquitos silvestres no Estado de São Paulo, Brasil. Rev Saúde Pública 2: 111-173.

Giglioli G 1948. An investigation of the housefrequenting habits of the British Guiana Coastland in relation to use of DDT. Am J Trop Med 28: 4370.

Gomes AC, Forattini OP, Natal D 1987. Composição e atividade de mosquitos Culicidae. Emprego de armadilha CDC no Vale da Ribeira, Estado de São Paulo, Brasil. Rev Saúde Pública 21: 363-370.

Guimarães AE, Arlé M 1984. Mosquitos no Parque Nacional da Serra dos Órgãos, Estado do Rio de Janeiro, Brasil. I - Distribuição Estacional. Mem Inst Oswaldo Cruz 79: 309-323.

Guimarães AE, Aguiar GM, Mello RP, Ribeiro CL, Jesus EP 1994. Ecologia de Mosquitos no Parque Nacional do Iguaçu, PR, Brasil. 1 - Dinâmica Populacional. In XX Congresso Brasileiro de Zoologia, UFRJ, Rio de Janeiro, p. 56.

Guimarães AE, Arlé M, Machado RNM, 1987. Mosquitos no Parque Nacional da Serra dos Órgãos, Estado do Rio de Janeiro, Brasil. IV - Preferência Alimentar. Mem Inst Oswaldo Cruz 82: 277-285.

Guimarães AE, Machado RNM, Neto B, Miranda KA 1991. Ecology of mosquitoes (Diptera-Culicidae) in the National Park of Serra da Bocaina and State Park of Serra do Mar, Rio de Janeiro and São Paulo, Brasil. I - Seasonal Variation. In II Simposio Internacional de Zoologia, Ciudad la Habana, Cuba.

Guimarães AE, Machado RNM, Miranda KA, Ribeiro CL 1992. Ecologia de mosquitos no Parque Nacional da Serra da Bocaina e no Parque Estadual da Serra do Mar, Estado do Rio de Janeiro e São Paulo, Brasil. II - Potencialidade de Domiciliação. XII Congresso Latino-Americano de Zoologia and XIX Congresso Brasileiro de Zoologia, Museu Paraense Emílio Goeldi, Pará.

Guimarães AE, Motta M, Arlé M, Machado RNM, Gonçalves LD 1989. Bionomia de mosquitos (Diptera-Culicidae) em áreas da Mata Atlântica no município de Itaguaí, Estado do Rio de Janeiro, Brasil. I - Freqüência intra, peri e extradomiciliar. Mem Inst Oswaldo Cruz 84: 243-254.

Harbach RE, Kitching IJ 1998. Phylogeny and classification of the Culicidae (Diptera). Syst Entomol 23: 327-370.

Haddow AJ 1954. Studies of the biting-habits of African mosquitoes. An appraisal of methods employed, with special to the twenty-four hours. Bull Ent Res 45: 199-242.

Haddow AJ 1960. Studies on the biting-habits and medical importance of east African mosquitoes in the genus Aedes. I- Subgenera Aedimorphus, Bankisinella and Dunnius. Bull Ent Res 50: 759-779. Judd DD 1996. Review of the systematics and phyloge- 
netic relationships of the Sabethini (Diptera: Culicidae). Syst Entomol 21: 129-150.

Judd DD 1998. Review a bromeliad-ovipositing lineage in Wyeomyia and the resurrection of Hystatomyia. Ent Soc Am 91: 572-589.

Lopes CM 1996. Estudos Preliminares da Diversidade da Fauna de Mosquitos (Diptera-Culicidae) em Áreas da Reserva Biológica do Tinguá, Estado do Rio de Janeiro, Brasil, Monography, Instituto Oswaldo Cruz, Fiocruz, Rio de Janeiro, 32 pp.

Lourenço-de-Oliveira R 1984. Alguns aspectos da ecologia dos mosquitos (Diptera: Culicidae) de uma área de planície (Granjas Calábria), em Jacarepaguá, Rio de Janeiro. I - Freqüência comparativa das espécies e métodos de coleta. Mem Inst Oswaldo Cruz 79: 479-490.

Lourenço-de-Oliveira R, Heyden R 1986. Alguns aspectos da ecologia dos mosquitos (Diptera: Culicidae) de uma área de planície (Granjas Calábria), em Jacarepaguá, Rio de Janeiro. IV - Preferências Alimentares quanto ao hospedeiro e freqüência domiciliar. Mem Inst Oswaldo Cruz 81: 15-27.

Lourenço-de-Oliveira R, Guimarães AE, Arlé M, Silva TF, Castro MG, Motta MA, Deane LM 1989. Anopheline species, some of their habits and relation to malaria in endemic areas of Rondônia State, Amazon Region of Brazil. Mem Inst Oswaldo Cruz.
84: 501-514.

Neves DP 1972. Alguns Aspectos da Ecologia dos Culicídeos no Parque das Mangabeiras, Belo Horizonte (MG), MSc Thesis, Universidade Federal de Minas Gerais, Minas Gerais, 75 pp.

Povolny D 1971. Synanthropy. In B Greenberg, Flies and Disease, Vol. I, Princeton Univ. Press, Princeton, p. 16-54.

Rachou RG 1946. Da enfectividade de anofelinos do subgênero Kerteszia pelos parasitas da malária humana. A Folha Med 27: 1-10.

Rachou RG, Lima MM, Ferreira-Neto JA, Martins C 1955. Inquérito epidemiológico da filariose bancroftiana em uma localidade de Santa Catarina. Rev Brasil Malariol e Doenças Trop 7: 51-70.

Rachou RG, Moura-Lima M, Ferreira-Neto JA, Martins CM 1958. Alguns dados sobre o comportamento de mosquitos de Ponta Grossa (Florianópolis, Santa Catarina). Rev Brasil Malariol D Trop 10: 417-427.

Roberts DR, Hoch AL, Peterson NE, Pinheiro FP 1981. Programa multidisciplinario de vigilancia de efermedades infecciosas an zonas colidantes con Ia Carretera Transamazonica en Brasil. IV - Estudio Entomologico. Bul Of Sanit Panam 91: 370-400.

Shannon RC 1931. The environment and behavior of some Brazilian mosquitoes. Proc Ent Soc Wash 33: $1-27$. 